\title{
Migration and women's health
}

\author{
Richard M.K. Adanu ${ }^{\mathrm{a}, *}$, Timothy R.B. Johnson ${ }^{\mathrm{b}}$ \\ a Department of Obstetrics and Gynecology, University of Ghana Medical School, Accra, Ghana \\ ${ }^{\mathrm{b}}$ Department of Obstetrics and Gynecology, University of Michigan Medical Center, Ann Arbor, Michigan, USA
}

\section{A R T I C L E I N F O}

\section{Keywords:}

Migration

Refugees

War

Women's health

\begin{abstract}
A B S T R A C T
Women have been migrating at similar rates to men for the past 40 years, and comprised about half of all migrants in 2005. Women and children are most affected by displacement as a result of wars and human trafficking. In some cases, the health of female migrants is improved via integration into better health systems in the host country. More often, however, the health of female migrants is affected negatively. Women are doubly disadvantaged because they are discriminated against as women and as migrants. Female migrants are also highly vulnerable to acts of sexual abuse, rape, and violence. This is especially true for women in refugee camps, whose reproductive health needs are often overlooked. To improve the health of female migrants it is important to develop and implement policies that recognize and insist on the respect of the rights of migrants.
\end{abstract}

(c) 2009 International Federation of Gynecology and Obstetrics. Published by Elsevier Ireland Ltd. All rights reserved.

\section{Introduction}

Migration has always been a major cause of population change. Within countries people migrate from rural to urban areas to search for better employment and to improve their socioeconomic conditions. A similar pattern is seen with migration from low-income countries to high-income countries, mainly for financial reasons. In recent years another factor has been introduced as a cause of migration: the increase in the number of wars around the world. Civil wars and tribal conflicts occur in a number of low-income countries and result in deaths and displacement of large numbers of people. These displaced people usually have no option but to migrate from their homes to find new places to live, either within or outside their country. The majority of people affected by this forced movement are women and children [1]. Migration is therefore a factor that must be considered in today's issues surrounding women's health.

\section{Women as migrants}

Because migration is usually associated with the search for jobs it is generally believed that most voluntary migrants are men. However, estimates from the United Nations Population Division show that women have been migrating at a similar rate to men for the past 40 years [2]. Focusing on international migration, it is estimated that women comprised 50\% of migrants in 2005 [3]. When the figures for displacement resulting from wars are considered, women form the majority of migrants globally. When men who are fathers migrate in search of jobs, there is usually little pressure that their children will join them. In most cases, men leave their children behind in the care of

\footnotetext{
* Corresponding author.

E-mail address: rmadanu@yahoo.com (R.M.K. Adanu).
}

the mothers. However, the situation is different when women migrate. Gender roles in most cultures lead to the expectation that women will serve as the direct caregivers for the children. The result is that most mothers who migrate are still faced with the direct pressure of caring for their children. These women are under pressure to settle quickly in their new places of residence so that they can be joined by their children. Women who migrate from low-income countries often leave their children in the care of other family members and not necessarily with the fathers. This situation only serves to increase the pressure to get their children to join them.

Women who are displaced as a result of war usually move with their children and, because these women are usually the primary caregivers, they have the responsibility of ensuring that their children get food and other necessary resources, even though they are in a situation where they usually do not have the means of earning an income.

Lack of basic sanitation and public health services often compound the lack of healthcare services for these refugees. Another dimension of migration is human trafficking; and most of the victims are women. Some of these women become the victims of traffickers because they need to improve their economic situation, while others are deceived and then transported from their countries and forced to work to stay alive. Women in such situations may originate from an environment of violence and abuse and can end up as victims of violence, rape, and abuse. It is estimated that about 2 million individuals are trafficked annually and the majority of these are women and girls [2].

\section{Health effects of migration}

There have been several observations about the health of migrants. One is that most voluntary migrants are generally in better health than others in their country of origin because only healthy people will decide to or be given the opportunity to migrate to search for jobs [2]. 
There have also been reports of migrants achieving a better health status than in their countries of origin when the migration is from low-income to high-income countries [4].

There are 3 models that try to describe the health effects of migration. One is that as migrants are exposed to the living conditions of their host country, they end up with health indicators that are similar to that of the host country [2]. Another theory is that the stress of having to settle in a new environment tends to have a negative effect on the health of migrants [2]. The third model postulates that there is an interaction between the stressors that lead a person to migrate and the stressors involved in settling, and this interaction determines the health status of the migrants [2]. Each of these theories recognizes the contribution of the other two, which suggests that there are multiple determinants of the health of migrants.

People who are displaced as a result of war are usually in a worse state of health than the residents of the host country. Armed conflicts also cause a rapid deterioration in the health status of the resultant refugees [5]. The conditions under which most of these displaced people live in the host country do not usually promote good health [6]. It has been reported that the reproductive health needs of women are often overlooked even in the most organized refugee camps [6]. The insensitivity of health workers to women's needs is also more pronounced in these camps [6]. Rape is used as a tactic of war and women who have suffered such violence are sometimes subjected to similar or even greater abuse in refugee camps [5]. A study of domestic violence in refugee camps in Jordan showed a high level of acceptability of domestic violence among both men and women [7]. This could suggest high levels of domestic violence in refugee camps.

Most migrants are never fully integrated into their host countries [6]. They are faced with discrimination in many ways, for example when looking for jobs. Many migrants are also unable to attain the level of social importance they could have attained at home in their host country. These factors end up affecting the psychological health of migrants. In extreme cases, migrants who appear to be doing better than the nationals in the host country may become targets of violence in xenophobic attacks.

\section{Migration and women's health}

The effects of migration on women's health are varied. Migration could result in the worsening or improvement of the health of a woman. The resulting health effect of migration is determined by the conditions under which the migration occurred, the extent of integration into the host society, the social status of the woman in the host country, and the prevailing health conditions in the host country.

A cohort study by Hawkins et al. [8] revealed the effect of the existing maternal health behaviors on women migrating into the UK. It has been shown that more drinking and smoking during pregnancy occurs among white British/Irish mothers compared with women in South Asia, the Caribbean, and Africa. There is also less breastfeeding among white British/Irish women. The study by Hawkins et al. [8] showed there was less smoking, less drinking, and more breastfeeding among migrants in the United Kingdom than among white British/ Irish women. However, the study found that female migrants who had stayed longer in the UK were more likely to smoke and drink during pregnancy and less likely to breastfeed than female migrants who had not been in the UK for a long time. These findings are supported by observations made by Kornosky et al. [9].

Women who migrate from low-income to high-income counties are more likely to benefit from the health system of the host country if they speak the language of the host nation and have jobs. These women benefit from programs for cervical and breast cancer screening that may not be available in their home countries, with a resultant improvement in health status. However, women who do not speak the language and do not have jobs are less likely to benefit from the health system of the host nation [10]. These women are usually dependent on men and may be unable to access the health system because of lack of health insurance and problems arising from male dominance [6,11]. Being unable to speak the national language keeps these women from learning about the available health services [11]. However, it has been reported that in some cases migration to high-income countries could result in a positive change to men's level of involvement in pregnancy care, thereby improving maternal health [4].

Women do not have a high status in many societies throughout the world. Women who are migrants are therefore doubly disadvantaged. They are not regarded, firstly because they are women, and secondly because they are migrants [12]. Female migrants are highly vulnerable to acts of sexual abuse, rape, and violence $[6,13]$ and may not be able to seek redress through the legal system of the host nation [13]. This situation is especially prevalent when women have become migrants as a result of wars in their home country or when they are victims of human trafficking. These women live in fear of both the national authorities and the people responsible for maltreating them. Similar situations can arise when women migrate voluntarily for economic reasons, but do not have the appropriate immigration documents to cover their stay. Some women travel to high-income countries with false documentation to serve as domestic help for other migrants. Even when they travel with genuine documents, such women do not have the economic means to leave such "employment" if they are unhappy and they may not have access to their own documents. The fear of facing the unknown in a foreign country ensures that many women continue to suffer the dehumanizing conditions they live and work in, or continue to suffer repeated violence and abuse.

Even when women do not migrate, their health status can be affected by migration. It has been shown that women whose partners travel frequently are at higher risk of HIV infection than women whose partners do not travel [14].

\section{Improving the health of female migrants}

To improve the health of female migrants it is important for all countries to develop and implement policies that recognize and insist on the respect of the rights of migrants regardless of their immigration status. There is a need to be more vigilant in both host and home countries regarding detection and prosecution of people who engage in human trafficking. Prospective migrants need to be clearly informed about their rights and responsibilities in the countries they are migrating to. This can and should be done in both the home countries and the host countries. When migrants are in refugee camps, governments should ensure that appropriate health services are provided that adequately address all aspects of women's health, particularly reproductive and sexual health. It must be remembered that these women often arrive in poor health and with immediate, short-term, and long-term health needs, many of which reflect reproductive health. It is also necessary for all agencies and professional bodies involved in women's health to continually raise the issue of the health and human rights of female migrants.

\section{Conclusion}

Migration is a major issue facing the world today. The negative health effects of migration are more prominent for women than men. It is important that women's health advocates become involved in improving the health of migrants.

\section{References}

[1] Al Gasseer N, Dresden E, Keeney GB, Warren N. Status of women and infants in complex humanitarian emergencies. J Midwifery Womens Health 2004;49 (4 Suppl 1):7-13.

[2] Llacer A, Zunzunegui MV, del Amo J, Mazarrasa L, Bolumar F. The contribution of a gender perspective to the understanding of migrants' health. J Epidemiol Community Health 2007;61(Suppl 2):4-10. 
[3] International Organization for Migration. Global estimates for migration; 2008 Available at: http://www.iom.int/jahia/Jahia/facts-and-figures/global-estimatesand-trends/. Accessed September 10, 2008.

[4] Ny P, Plantin L, Karlsson ED, Dykes AK. Middle Eastern mothers in Sweden, their experiences of the maternal health service and their partner's involvement. Reprod Health 2007;4:9.

[5] Rojnik B, Andolsek-Jeras L, Obersnel-Kveder D. Women in difficult circumstances: war victims and refugees. Int J Gynecol Obstet 1995:48(3):311-5.

[6] Carballo M, Grocutt M, Hadzihasanovic A. Women and migration: a public health issue. World Health Stat Q 1996;49(2):158-64.

[7] Khawaja M. Domestic violence in refugee camps in Jordan. Int J Gynecol Obstet 2004;86(1):67-9.

[8] Hawkins SS, Lamb K, Cole TJ, Law C. Influence of moving to the UK on maternal health behaviours: prospective cohort study. BMJ 2008;336(7652):1052-5.

[9] Kornosky JL, Peck JD, Sweeney AM, Adelson PL, Schantz SL. Reproductive characteristics of Southeast Asian immigrants before and after migration. J Immigr Minor Health 2008;10(2):135-43
[10] Bollini P, Stotzer U, Wanner P. Pregnancy outcomes and migration in Switzerland: results from a focus group study. Int J Public Health 2007;52(2):78-86.

[11] Carballero M, Leyva-Flores R, Ochoa-Marin SC, Zarco A, Guerrero C. Women who are left behind: the impact of international migration on the process of seeking health care [in Spanish]. Salud Publica Mex 2008;50(3):241-50.

[12] Feng W, Ren P, Shaokang Z, Anan S. Reproductive health status, knowledge, and access to health care among female migrants in Shanghai, China. J Biosoc Sci 2005;37(5):603-22.

[13] Perruchoud R. The human rights of migrants - A shared responsibility; 2008. International Organization for Migration website. Available at: http://www.iom.int/ jahia/webdav/shared/shared/mainsite/published_docs/periodicals_and_newsletters/ migration_july08_editorial.pdf. Accessed September 10, 2008.

[14] Msuya SE, Mbizvo E, Hussain A, Uriyo J, Sam NE, Stray-Pedersen B. HIV among pregnant women in Moshi Tanzania: the role of sexual behavior, male partner characteristics and sexually transmitted infections. AIDS Res Ther 2006;3:27. 